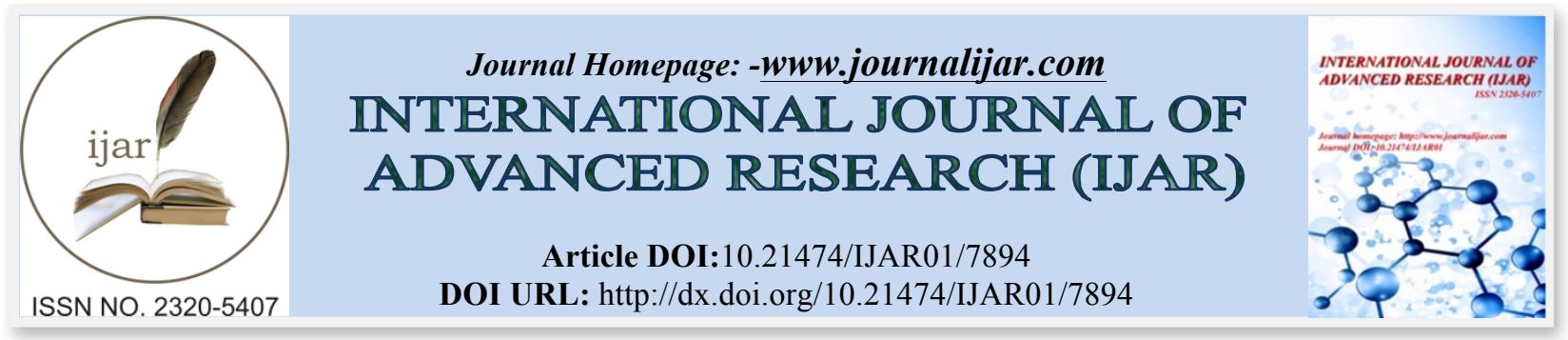

RESEARCH ARTICLE

\title{
ROAD INFRASTRUCTURE DEVELOPMENT AND SOCIAL EQUITY IN PAPUA PERSPECTIVE OF THE POPULATION IN RURAL AREAS IN MAIRASI, KAIMANA REGENCY, WEST PAPUA.
}

\author{
Nicolaas E. Kuahaty, Jeremias T. Keban and Sigit Priyanto. R.Rijanta \\ 1. PhD Student of Faculty of Social and Political Sciences Gadjah Mada University. \\ 2. Professor of Faculty of Social and Political Sciences, Gadjah Mada University. \\ 3. Professor of Transport Engineering, Gadjah Mada University. \\ 4. Professor of Geography, Gajah Mada University
}

\section{Manuscript Info}

Manuscript History

Received: 11 August 2018

Final Accepted: 13 September 2018

Published: October 2018

Keywords:-

Accessibility, Road infrastructure,

Social equity, Policy evaluation..

\section{Abstract}

The objective of this present research is to analyze the relationship between the policy of road infrastructure development and social equity in Papua, especially in rural area in Mairasi, Kaimana, West Papua. To get the needed information, a quantitative-qualitative or mixed method was employed to evaluate the policy. An after and before evaluation type was used to analyze the impacts of the socioeconomic changes before and after the road was built. This present research was focused on the accessibility impacts on the access to education, health, market and banking. The tool for the analysis was the Wilcoxon Signed Rank Test. The results of the analysis showed that the access to education had the mean value of 2.40 which is higher than that before the roads were built, namely 2.29 . The discrepancy is significantly meaningful where the p-value was 2.20 . The access to the market showed the mean value of 2.35 , which is higher than the mean value before the roads were built, 2.04 where the discrepancy is said to be significantly meaningful with the p-value of 0.000 . Then the access to banking had the mean value of 2.54 where it is higher than that before the roads were built, 2.04, and this discrepancy is significantly meaningful with the $p$ value of 0.000 . The results of the analysis showed that the development of the road infrastructures had significant impacts on the access to education, health, market and banking among the population dwelling in Mairasi rural areas. Moreover, the evaluation of the policy performance resulted in the proper policy in terms of services effectiveness, construction cost efficiency, responsiveness to isolatedness, equal distribution to limit the gaps, adequacy in solving socio-economic problems, and the fulfillment of equity aspects intended to maximize the population prosperity in the rural area in Mairasi.

Copy Right, IJAR, 2018,. All rights reserved.

\section{Introduction:-}

"It is about social equity", a firm and simple answer given by Joko Widodo, the President of the Republic of Indonesia in the opening of the Indonesian National Student Movement (GMNI) Congress in 2017 in Manado, 
North Sulawesi when he was asked about a high attention given by the government in developing Papua, especially in building the road infrastructure in rual areas in Papua known as trans-papua. The attention of the government to Papua is backgrounded by a great inequality between this area and other areas in Indonesia in terms of various socio-economic aspects.

Such en equality is the impacts of the unequal distribution of the infrastructure development in Papua. The development has merely been prioritized in the West Area of Indonesia, especially in Java, meanwhile the infrastructure development in Papua has been focused on the capital cities of regencies as the centre for growth. The paradigm of such a central development approach to the growth area to give a trickle down effect on the peripheral area is far from the expectation. Even this approach may result in a wider gap marked by a high level of poverty. The data from the Central Bureau of Statistics in 2016 showed that nationally Papua and West Papua provinces occupied the highest and the second highest ranks in Indonesia, namely $31 \%$ and $23 \%$, respectively in terms of poverty. In Kaimana, of which the present research was focused on, had the percentage of poverty of $18 \%$ where the highest level of the poverty in rural and urban areas is $37.94 \%$ and $5.68 \%$, respectively (Central Bureau of Statistics of Kaimana, 2014).

The isolatedness of an area is the main factor influencing the poverty condition in Papua where it may give impacts on the low level of education, health, housing, fresh water and electricity. Its geographical condition in the context of the development of the area may be considered as the aspect that may influence the extreme slope topography with low population density. Moreover, the limited road infrastructure that supports the accessibility of the movement of people, goods and services causes the people in rural areas to be difficult in solving the socioeconomic problems. According to Kasiyanto (1996), the population in kampongs in Papua is rare, as a result, it is not beneficial if the government allocates a great fund for the roads development, and it is better for the government to allocate a great fund to fulfill other urgent needs in the form of social assistances such as Direct Social Assistance BLT), Rice Assistance for the poor (Raskin) intended to improve the standard of living of the people by fulfilling their needs for foods and increasing the amount of money circulation through activities planned and conducted by the people themselves. It is a pity that these programs merely helped the people in the short-term fashion, even they gave the impacts of dependence on such social assistances and did not assist the people to be independent in term of their economy.

Therefore, the policy of the road infrastructure development should be led to encourage the people to be independent and the policy should be long-term in nature. Road is one of the vital infrastructures in the effort to improve the development of an area and people's prosperity, especially the people dwelling in rural areas. The availability of road networks with adequate quantity and quality in proper areas in rural areas will improve the accessibility of the people in the concerned areas to the basic, social, and economic infrastructures and facilities needed. Increasing accessibility gives better opportunities for the rural people to do their various socio-economic activities to improve their prosperity.

The rural area in Mairasi is one of the areas in Kaimana regency, West Papua province located in an isolated peripheral area. The powerlessness of the people to access the market makes them merely work to fulfill their need for foods (consumption), instead of doing economic scale activities. This area is very potential due to its natural resources with high economic values such as nutmeg, coffee beans, lawang and masohi tree bark which have not been maximally exploited. It seems that the justice is still far for the people living in the rural area in Mairasi.

The roads development is a form of equality to diminish the socio-economic inequality experienced by the people in rural areas. Therefore, this present study was expected to prove whether the roads development would give significant effects on the socio-economic changes of the people living in rural area in Mairasi as the realization of social equity as indicated by easy access to education, health, market and banking. The four variables were chosen because in the long run, the improvement of accessibility through the roads development would give impacts on the human building namely education, health and the purchasing power parity which in turns will reduce the inequality.

\section{Review Of Related Litrature Inequality and Poverty in Rural Areas}

Rural area is a region with agriculture as its main activity, including natural resource management and its with areas structured as rural residences, human government services, social services and economic activities." (Article 1 Verse 9 of the Law No. 24 year 1992 regarding Spatial Management). 
The development with the emphasis on the economic growth has resulted a wide gap between cities and village or urban and rural areas. The city as the center for growth is expected to give trickle down effects on rural areas. But, the reality is far from the expectation. Unequal development occurs especially in the income, spatial, and sectorial aspects. This unequal distribution of income triggers some income inequality where it serves as the beginning of the occurrence of poverty. From the spatial side, isolatedness or backwardness factor also contributes to trigger the poverty. Chambers (1998) said that one of the important dimensions contributing to influence the poverty is either geographical or sociological isolatedness. From the sectorial aspect, the excellence sector with abundant resources gives a great contribution to the development, while the non excellence sector merely burdens the development. It means that poverty is the fruit from the inequality. Therefore, the proper handling of the inequality will give effects on the socio-economic changes that in turn give impacts on the reduction of poverty.

Sharp, et.al (in Kuncoro, 1997) tried to identify the causes of poverty from the economic side. Firstly, in a micro scope, poverty occurs because of dissimilar patterns of resources ownership that may cause unequal incomes. The poor just possesses limited amount and low-quality resources. Secondly, poverty happens due to differences in the quality of human resources. Low quality of human resources means low productivity, which in turns causes low wages. This low quality of human resources is caused by low education, less lucky fate, discrimination, or descendant. Thirdly, poverty emerges due to different access to capital.

The three causes of poverty disemboque in the theory of vicious circle of poverty stating that according to Ragnar Nurkse (in Kuncoro, 1997): the backwardness, imperfect market and lacking of capital cause low productivity. Low productivity results in low incomes the people get. These low incomes then imply low saving and investment. The low investment causes backwardness, and so on (see Picture 1).

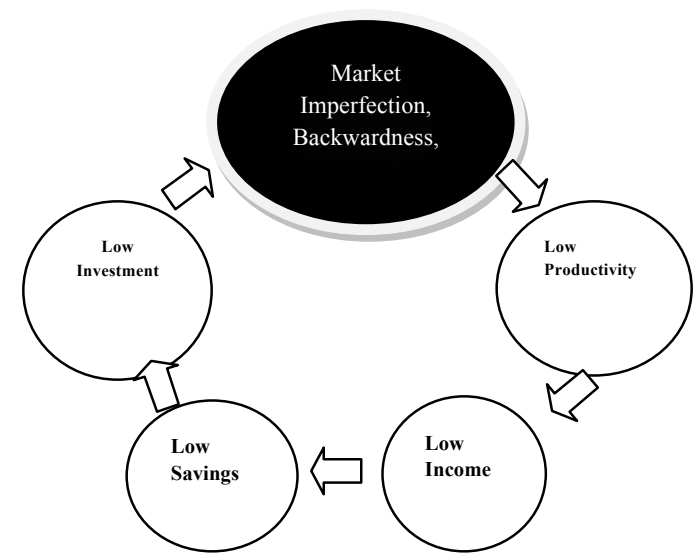

Picture 1:-Vicious Circle of Poverty (Ragnar Nurkse, in Kuntjoro 1997 p. 132)

The population dwelling in rural areas will be difficult to get out of the vicious circle of poverty without any revolutionary actions in the form of social investment that gives economic impacts through the improvement of accessibility. Good accessibility will become a leverage of socio-economic problems for the people living in rural areas. The basic question for the people living in rural areas with characteristics of potential agriculture is how they improve their productivity. If the pattern of the transportation of the production results and other goods or services still uses the pattern of the traditional transportation using persons or animals, they will never get out of the vicious circle of poverty.

Amarta Sen (1981) proposed that the cause of the eternity of poverty, powerlessness, or backwardness is accessibility. The people face limited choices to determine the continuation of their lives. If people are limited to and are not given access, it means they "they merely do what they should not do instead what they have to do." Therefore, their potential to develop their lives is hindered and at last this may contribute to create smaller mutual prosperity.

As a result, poverty and accessibility become hot debates. Limited or low accessibility causes high poverty in rural areas or high poverty in rural areas is caused by limited accessibility in rural areas. 


\section{Accessibility and Social equity Importance of Accessibility}

The essence of developing a road is what for and for whom the road is built. Black (1981) stated that accessibility is a concept combining a geographical land use management and a transportation network system connecting it. Then Hurst (1974) said that accessibility is the measure of convenience (time, cost or effort) in moving among places or areas in a system. Effort in this context is mobility or trip generation. Meanwhile, Edmonds (1994) stated that the indicator of accessibility is a numeric value, indicating the convenience or difficulty in getting an access to goods and services. According to Tamin (2000), the indicator of accessibility may simply be stated with distance. If a place is near with another place, it is said that the accessibility between the two places is higher. Whereas, if the two places are far, it means that the accessibility between the two places are low. Besides distance and time, expense is also an indicator of accessibility. If two places need a short travelling time, it can be said that they have high accessibility. Expense may also show the level of accessibility. Cost here is the one combining time and expense as a measure for the transportation relation (Mohammed, 2010). Based on the explanations of the concept accessibility, it can be concluded that accessibility becomes the factor pushing the development of an area or region in the mobility of the movement of people, goods and services.

According to Dennis (1998), there are two benefits from the improvement of accessibility. The first is direct benefits, namely a more convenient access to various facilities related to the provision of services given by the facilities. The second is secondary benefits covering the saving of time, effort, and transportation expense. More convenient accesses to various facilities are among others accesses to education, health, market and banking. Parikesit (2003) provides parameters to identify the priority zone in improving the access to education, health and market. Education is the basic need in this modern era. Most villagers have assumed the importance of education for their children. Therefore, it is important for the villagers to have access to basic education. The information required to identify the priority zone for improving the access to elementary education is as follows: the number of population in a certain zone, the location of the school, the distance to the school, time needed to go to the school, the expense for going to the school and the people's perception of the problem and priority. The development of a health service system for mothers, children and society is an important factor that influences the level of health. As a result, the government should make certain that the villagers have health facilities and an access to the center for health service. Information needed to identify the priority zone for improving the access to the health facilities is as follows: the number of population, the location of the health facilities, the transportation facility and infrastructures to the center for the health service, the distance to the center for the health service, time needed to go to the center for the health service, the expense for going to the center for the health service, and the people's perception of the problem and priority. The center for trade (market) is a place for providing various types of life necessities, either for the buyers or the sellers. The facility to reach this facility may reduce the expense needed. Therefore, it is important for the villagers to have an access to the market. The information needed to identify the priority zone for improving the access to the market is as follows: the number of population, the location of the health facilities, the transportation facility and infrastructures, the distance, the time, the expense to the market and the people's perception of the problem and priority. Concerning the access to banking, the indicator refers to the people's saving and loan activities in the banking system.

The development of roads is the realization of the availability of accessibility, rural infrastructure, including roads as one of the basic needs of development in the context of rural poverty reduction and inclusion. Road infrastructure in rural areas is the preliminary part of the development in rural areas (IFAD, 2016). Ekong (1988) defines rural infrastructure as "“'a basic physical, social and institutional form of capital which enhances rural dwellers' production, distribution and consumption activities and ultimately the quality of their lives." Then Cesar Queiroz and Surhid Gautam (1992), state that "Road transport is an important sector of economic activity, especially in developing countries, where it plays an essential role in marketing agricultural products and providing access to health, education and agricultural inputs and extension service." Specifically Warr (2005) stated that limiter road network will cause isolatedness that hinder the people to go out of various problems in development such as low access to education. moreover, Dunkin (1992) stated that when the access to a health facility is better, the people will have "good health" According to Maghriby (2004), the improvement of an access to the health facility is expected to improve the villagers' life quality. Less fertile land may be improved by a good land processing and the use of fertilizers, the use of quality seeds. Good access to the source of information, and various services facilities such as schools, Community Health Centers, markets and the like will improve the quality of the use and development of natural and human resources and the community economy. 
Therefore, a structured plan of the rural road network development is required to improve the accessibility to rural areas and to avoid any waste in the use of sources and to make certain the resulted benefits. The availability of a rural road network developed with high quality and in proper locations will be able to improve the accessibility of the concerned population to the basic, social and economic infrastructury and facility needed. The provision of the infrastructure and facility is intended to push the people to move from a traditional life with a subsistence system where the agriculture is managed as an activity into a modern agriculture-based society with a market orientation namely an activity with economic value or economy of scale so that the farmers' position will increase or the society will get adequate incomes. Therefore, the society will have opportunities to have rational choices for better and quality education and for quality health care, especially the high-quality and the best facilities of medical workers.

The factor driving the transformation process of this paradigm is greatly influenced by the improvement of accessibility namely the availability of reliable and adequate roads as a structural change process. A structured development of the road network will will promote the realization of the connectivity as the prime mover of the people's economy.

\section{Social equity}

Road development is a policy of distribution intended to fulfill the function of the government in conducting its tasks. Road development is the realization of the distribution equity. Road in the context of this present research is categorized into pure public goods. In the theory of public finance, Gruber (2011-182) states that "“Pure public goods are goods that are perfectly non-rival in consumption and are non-excludable". The effort made by the government to provide the public goods in general is oriented into answering four questions on public finance as stated by Gruber (2011: 3):

"When should the government intervene in the economy? How might the government intervene? What is the effect of
those interventions on economic outcomes? Why do government choose to intervene in the way that they do?"

Public scope according to Bovaird and Liffler (1993: 4) is " "'the arena in which public choice is exercised in order to achieve a collective purpose". Then it is added that "the concept of 'public' generally means that the providers have to observe and satisfy some forms of public service obligation". Parsons (2001: 3) stated that public itself contains human activities which are seen to be necessary to be regulated or intervened by the government or social rules or at least by joint actions. In the article 62 verse (1) item c of the Law no. 38 year 2004 regarding Road, it is mentioned that the people have rights to get benefits of the road management with the determined minimum service standard. in short, each public policy made by the government, including the road development, is expected to give benefits to the society. Dunn (2004: 5) calls it with the term preferred policy. The preferred policy should be the solution to the problem the public encounters. In the context of this present research, the development of the road network should be able to support the betterment of the prosperity of villages in Mairasi, Kaimana regency.

According to John Bradley Rawls (1997), distributive justice in accordance with its characteristics is divided into three types namely equality, equivalence and equity. Based on the common term and the conventional dictionary, the three labels of distributive justice possess similar definitions, but different meanings and implications for the development. Firstly, equality is distributional justice with the emphasis on the distribution of even primary social needs to the whole people, especially it is prioritized for the marjinal. The term the marjinal here refers to groups of people who are unlucky in terms of economic condition. Secondly, equivalence is a principle based on the contribution or proportion. Public policy is focused on in such a way that it gives benefits to individuals who give the most contribution. Thirdly, equity is a principle of distributional justice adhered by the concept of sustainable development. On the basis of the concept of the above-mentioned distributive justice, what is adopted by the government now is the principle of equivalence justice, where to keep the balance of the market and the development of an area, the development policy is focused on the economic growth with the expectation that it will give multiple effects to the surrounding or tertiary areas. But in fact, the approach has a risk namely it worsens the gaps among areas and classes of the people. Therefore, to reduce the gaps among areas and among regions, an equality and equity approach should be given a priority and also the realization of the presence of the state. The equality and the equity principle may result in innovative and sustainable policies.

As a result, as Frederickson in Gedeona (2004) puts it, the issue of social equity occupies an important position in making public policies. As one of the real instruments in the development process, a public policy should place the social equity as an important value in the value weighting adopted, since social equity may be used : (1) as the 
basis for a just democratic society, (2) as in influencing the behavior of organizational man, (3) as the legal basis for distributing public services, (4) as the practical basis for distributing public services, (5) as understood in compound federalism, and (6) as a challenge for research and analysis. Therefore, in making and implementing a policy, the government should be able to pay attention to the value of social equity in each decision and action made, so that the decision and action will not disserve the society, will not result in any imbalance in the society due to injustice in either the distribution or allocation of resources.

This road development encourages the movement from the barter into the market economy. Before the market existed, the public economy was facilitated by the barter economy, but after the isolatedness is opened, the barter economy has changed into the market economy. As a result, rural areas start to develop

As a comparison, the results of this research showing that significant impacts from the road infrastructure development on the people's socio-economic changes are in line with those of the following researches, among others: Iek (2013), Kesiddes (1993), Ningsih, 2010, Sarkar and Mashiri, (1998), Dardak (2005), Rao and Jayasree (2003), Afriansyah, Wicaksono, and Djakfar (2012), Liu (2000), Tigauw (2012).

\section{Research Methodology}

It was a policy evaluation with a sequentially mixed method design, especially the follow-up explanatory model. In this model, a quantitative approach first was adopted to collect the data and to support the analysis. Meanwhile, a qualitative approach was employed after important points from the quantitative approach were obtained. It is expected to be able to delineate a real condition in the field. Qualitative approach is especially used to give descriptions of the implementation of policies and the impacts experienced by the informants.

The respondents were 331 people dwelling in the rural area in Mairasi. Twenty five informants were chosen with the following criteria: the government staffs in Kaimana, prominent figures, general public, and local parliaments members of Kaimana.

The data management was done using a tool the researchers developed in the field namely the quantitative data that would result in raw data which then were transferred into SPSS for further analysis. Quantitative data would produce secondary data to process in the policy analysis. The results of the interviews would be recorded and transcribed, where the transcription/verbatim was then processed and analyzed using NVivo 12Plus application.

\section{Wilcoxon Signed Rank Test and Data Validity Test}

The medium of the quantitative analysis was the Wilcoxon Signed Rank Test, a non-parametric test to measure the significance of the differences between two groups of paired data with ordinal or internal scale but with abnormal distribution. To test the significance of the road development variable with the access variable namely education, health, market and banking, this analysis was built in the following hypotheses: Ho: $d=0$, namely the condition before and after the road is built is not different, and $\mathrm{Ha}: \mathrm{d} \neq 0$, namely the condition before and after the road is built is different. The basis for the decision making is as follows: If the Assym Value, Sig $<0.05$, Ho is not accepted, if the Asym Value, Sig $>0,05$, Ho is accepted. The validity and reliability testing is related to the research construct measurement. The validity and reliability testing is important for the construct because such a construct is often ambiguous, diffused and indirectly identified.

Then, validity and reliability testings were done. The validity testing was made by counting the correlation between each question and the total score, using the formula of Product Moment Correlation. The significance test was made by comparing the coefficient value of the correlation ( $r$-count) and the value of the r-table for the degree of freedom (df) $n-k$, where $\mathrm{n}$ is the number of the samples and $\mathrm{k}$ is the number of the independent variables at the significance level of $5 \%((\alpha=0,05)$.

If the value of the t-count (in the output of the SPSS is notated as the corrected item total correlation) is positive and the r-count is higher than the r-table, it can be said that the item of the question is valid, so is the opposite. To test the reliability, the testing instrument with the most proper internal consistency is the Alpha's Cronbach or alpha coefficient. The range of the alpha coefficient value is between 0 (without reliability) and 1 (perfect reliability). Some experts ((Bandur, 2013; Munning \& Munro, 2006; Gregory, 2000; Nunally, 1978) have determined the alpha coefficient value as follows : 
$0=$ no reliability

$>.70=$ Acceptable reliability

$>.80=$ good reliability

$.90=$ excellent reliability

$1=$ perfect reliability

The Cronbach's Alpha is the total score of the reliability variable tested in this research. Reliability test for each variable was made to see the correation among question items. If the correlation value is higher than the alpha value of the total variables, the question item should be deleted.

In terms of the substance, this research may be categorized into a policy evaluation research, especially the beforeafter comparison evaluation type as proposed by Dye (1992). The use of evaluation of the impacts of a policy in this present research is aimed at understanding socio-economic changes caused by the policy of the road infrastructure development in rural area in Kaimana regency. To reinforce the analysis, Dunn's (1981: 232-238) evaluation of policy performance was employed: effectiveness, efficiency, equity, adequacy, responsiveness, and appropriateness. The parameters of the policy evaluation are presented in Table 1.

Table 1:-Parameter of the Policy Evaluation

\begin{tabular}{|l|l|}
\hline \multicolumn{1}{|c|}{ Criteria } & \multicolumn{1}{c|}{ Parameter } \\
\hline Effectiveness & $\begin{array}{l}\text { Whether an alternative reaches the expected the intended result or the goal of an action. This criterion is } \\
\text { closely related to the technical rationality which is always measured from a unit of product or service or } \\
\text { its monetary value. }\end{array}$ \\
\hline Efficiency & Reaches the highest effectiveness with the lowest cost \\
\hline Adequacy & $\begin{array}{l}\text { How far a level of effectiveness satisfies needs, values and opportunities that need problems. The } \\
\text { adequacy criterion gives an emphasis on a strong relationship between an alternative policy and its } \\
\text { expected result. }\end{array}$ \\
\hline Equity & $\begin{array}{l}\text { This criterion is related to a legal and social rationality and refers to the distribution of causes and efforts } \\
\text { among different groups in a society. An equity-oriented policy is the policy where causes or efforts are } \\
\text { justly distributed }\end{array}$ \\
\hline Responsiveness & $\begin{array}{l}\text { Row far a policy may satisfy the needs, preferences, or values of certain groups of people. } \\
\text { for the goal. Meanwhile, all other criteria do not question the goal, for example the value of efficiency } \\
\text { and sameness, but it is the appropriateness criteria which question whether the gol is appropriate for a } \\
\text { society. }\end{array}$ \\
\hline Appropriateness &
\end{tabular}

\section{Road Development Policy and Social Equity for Villagers in Mairasi}

The policy of the trans-Papua road infrastructure development is to establish a linear line as the main corridor of the connectivity among the cities, villages, coastal regions and rural areas. Connectivity in the attribution of the Asymmetry policy in Papua through the Law no. 21 year 2001 means that the infrastructure development at least in period of 25 (twenty five) years is aimed at connecting all cities in the provinces, regencies/cities, districts or other centers of population either through high-quality land, sea and air transportations in the period of at least 20 (twenty five) years, so that the Papua province may conduct their economic activities well and beneficially as part of the national and global economic systems. The development of the connectivity is intended to make sure that no meaningful hindrances exist in the logistics flow of goods or people in the peripheral regions.

The policy of the road infrastructure development in rural area in Mairasi, Kaimana regency, West Papua as stated in the Local Medium-Term Development Plan (RPJMD) years 2010-2015 and 2016-2021 is an effort to improve the accessibility in rural areas. The Lobo - Jarati - Matua road is the regency road with the length of $60 \mathrm{Kms}$. This road connects 5 (five) kampongs namely Lobo, Jarati, Orai, Werua and Sara to Matua. The road is connected to the national road, Kaimana - Triton. The road connecting Lobo - Jarati - Matua is specifically passes through the slopes, mountains, and valleys. This road was working on from 2012 to 2017 (23Kms) with the budget of Rp.66.773.668.996. The type of the construction adopted is Weatherproof Solid Aggregate Road (JAPAT). The location of the Lobo- Jarati - Matua road is presented in Picture 1. 


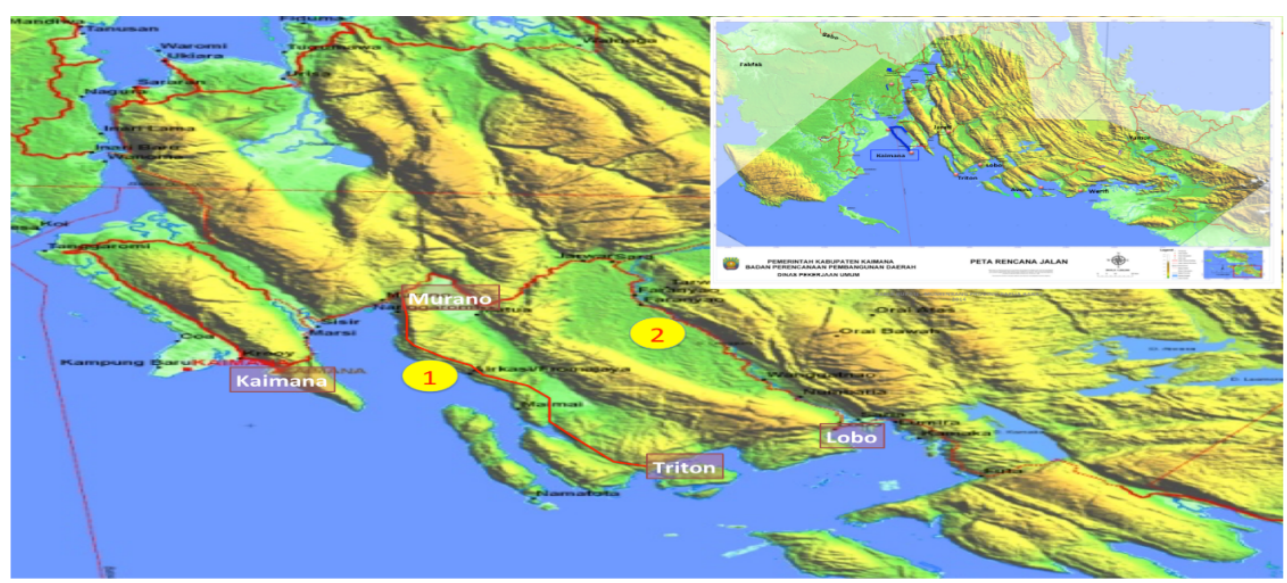

Picture 1:- Map of Lobo - Jarati - Matua Road

\section{Condition of the Population before the Road Development}

Isolatedness of rural population in Mairasi made them difficult get out from poverty or stay in the vicious circle of poverty. It is as if that various socio-economic problems become a blurred display window of the condition of population of the rural area in Mairasi. They were trapped into an ironical motto: ekonomi tiba berangkat, meaning that what is obtained today is also spent today. It cannot be denied that the natural resources which are abundant and are easily obtained made the people always think pragmatically. They did not earn adequate incomes or the exchange values of the farmers in the area are low. This is due to their low productivity. Actually the people had a great potential to plant nutmeg, coffee, masohi and lawang tree barks, but because it takes about 4-5 day walk to take the products to the market, they cannot do their business well. Usually had a profit sharing system in bringing their products to the market. The owners of the goods get $30 \%$, while the rest, $70 \%$ is given to the persons who carry the products to the market. So the profit sharing is $30: 70$ where $30 \%$ is for the owner and $75 \%$ for the carrier. Moreover, the access to education and health was also still limited. Concerning the basic health service, sometimes medical staffs visited the places once a month, even the level of attendance or awareness of the people of the health services was very low. This condition was bad since even supposing that there was a person suffering from a high risk disease and had to be brought to the city for further treatment, the people there tended to give up.

In the field of education the number of students' participation was low; even the students who continued their study to further education in the city were also limited in number. However, it should be admitted that the assistance for elementary education in Lobo kampong as the kampong in a rural area was adequate, but since it was very difficult for the people in some other kampongs to reach the location of Lobo kampong, this condition made the people not continue their education in the city. It can be imagine how difficult it is for the people in rural areas in Mairasi to get out of their socio-economic problems. 
The flow of thought in this journal is presented in Picture 4
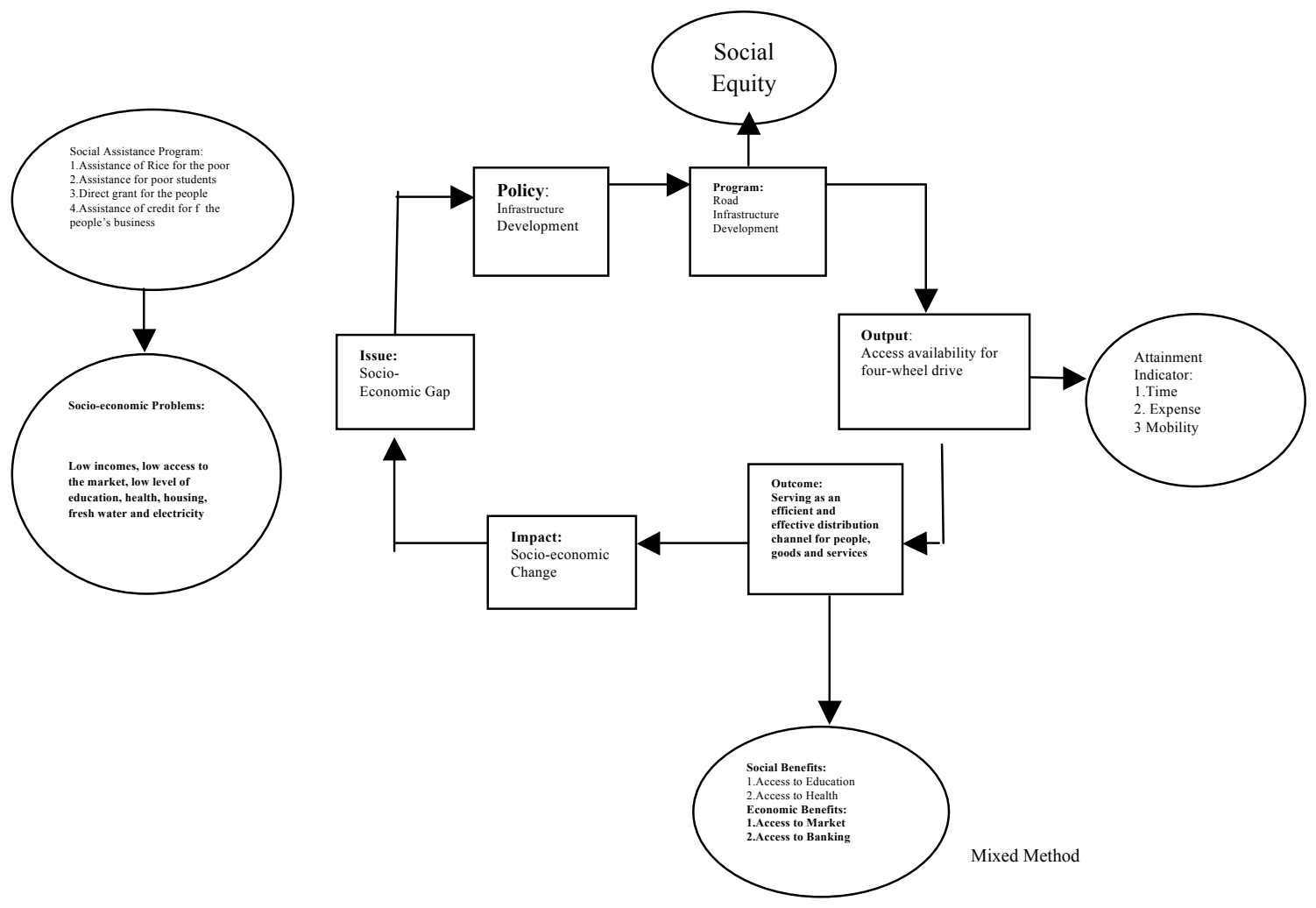

Source: Modified Research Data

Picture 3:-Flow of Thought of Road Infrastructure Development and Social Equity

Road is the realization of social equity, since it is able to change the pattern of movement of people, goods and services, from the traditional pattern of movement using human beings and animals as the transportation tool into a modern pattern of movement using motorized-transport tool.

\section{Result And Discussion:-} Impacts of Road Development on Accessibility Improvement

Accessibility is the level of convenience a society reaches to come to an object, a service or an environment. Therefore, the convenience of the access is usually implemented on the road. There are 3 indicators of accessibility covering mobility, time spent for the travel and travel expense. The three indicators include access of the villagers in Mairasi to education, health, market, and banking.

\section{Access to Education}

The indicators of the access to education in this present research deal with the evaluation of the people to the convenience of students, teachers, parents in coming to the school location, the availability of educational facilities and infrastructures and educational cost. The evaluation covers the conditions before and after the policy of the road development in rural area in Mairasi.

The results of the statistical data showed that the mean value of the access to education after the road was built was 2.40 , which is higher than that before the road is development, namely 2.29. The discrepancy is statistically significant since it possesses the $Z$ value of -5.122 with the $p$-value (Asymp. Sig 2-tailed) of 0.000 , so it is below the research critical limit, 0.05 . Therefore, the decision is that Hol is not accepted or Ha1 is accepted, meaning that there is a significant discrepancy of the access to education, before and after the road is built. It can be stated that the policy to develop the road infrastructure brings a significant change to the access to education in rural area in Mairasi. 
The condition of the change is realized in the convenience the people felt in enrolling their children or facilitating their children's needs at school. The students may go to and fro from the school quickly. Moreover the condition also has encouraged the teachers to visit their students when the students do not go to school. This confirms the fact that road plays a vital role or serves as the vein of education and this may give a better accessibility to the convenience of the students, teachers, and parents when they go to their school location.

There is an important finding dealing with the students who did not go to school for certain reasons such as raining or family events. In this case, the teachers visited them in kampongs to give them lessons as an effort to maximize the benefits of the road in the access to education. The change had not been revealed in previous researches. This condition may reduce the parents' worries with their children since they should pass through the forest to go school. The children were used to ride trucks provided by the government or the companies around the road. The statement confirms that the policy of the road infrastructure development may result in socio-economic changes to the people who do not dwell along the road in the rural area in Mairasi. As a result, the people who are not dwelling along the road still need an access to come to the main road by building local roads of which two-wheel vehicles may pass through. Therefore, they may cut the travelling time, as one of the important criteria of the existence of a road: improving the people's accessibility to education infrastructures and facilities. In the context of regional development, the policy of the road development, especially in determining the location or the road trace, needs a comprehensive study with the consideration of the distance and topographic condition in order to fulfill the essential rule of the road development namely: for what and to whom is a road to be built. For the access to education, it is shown that a significant development occurred where students in the rural area of Mairasi continued their study to the Junior High School and Senior High School/Vocational High School levels in the academic year of 2012-2017. See Table 1.1.

Table 1:-Development of Students' Education in the Rural Area in Mairasi into Junior High School and Senior High School/Vocational High School Level in the Academic Year of $2012-2017$

\begin{tabular}{|c|c|c|c|c|c|c|c|c|c|c|c|c|}
\hline \multicolumn{13}{|c|}{ YEAR } \\
\hline Kampong & \multicolumn{2}{|c|}{2012} & \multicolumn{2}{|c|}{2013} & \multicolumn{2}{|c|}{2014} & \multicolumn{2}{|r|}{2015} & \multicolumn{2}{|c|}{2916} & \multicolumn{2}{|c|}{2017} \\
\hline & SMP & SMA/SMK & SMP & SMA/SMK & SMP & SMA/SMK & SMP & SMA/SMK & SMP & SMA/SMK & SMP & SMA/SMK \\
\hline Jarati & 2 & 2 & 3 & 3 & 4 & 3 & 5 & 5 & 2 & 5 & 4 & 7 \\
\hline Weua & 1 & 2 & 2 & 3 & 3 & 3 & 4 & 3 & 4 & 4 & 5 & 5 \\
\hline Orai & 2 & 3 & 3 & 2 & 2 & 3 & 4 & 4 & 5 & 7 & 7 & 9 \\
\hline Sara & 3 & 5 & 7 & 7 & 5 & 6 & 3 & 4 & 8 & 8 & 10 & 10 \\
\hline Lobo & 13 & 15 & 15 & 17 & 19 & 15 & 21 & 32 & 18 & 35 & 30 & 38 \\
\hline
\end{tabular}

Note: SMP : Junior High School; SMA : Senior High School; SMK: Vocational High School

Source: Results of the Processed Primary Data, 2017

Education is one of the basic aspects in local development. Good education certainly supports the quality of superior human resources. Therefore, an access to education should be paid a serious attention in the effort to build a more advanced area. The accessibility to education is some convenience to lead to teaching-learning facilities. Dardak (2005) stated that rural roads may facilitate the people's reach to centers for social and cultural services such as educational infrastructures (school).

This condition also answers Warr's (2005) worries that a limited road network will cause some isolatedness that may hinder the people to go out of their various development problems such as low access to education. As a result, changes of access to education as one of the policies of the road infrastructures not only occur to the population in rural areas living along the road but also those who do not live along it.

The easiness of the access actually refers to the convenience of access to further education centered at the city. This happened because almost each kampong in rural area in Mairasi had possessed elementary school, meaning that the population living in rural area in Mairasi did not have any differences in their access to basic education. the existence of road infrastructure in rural areas that supports this accessibility has an important correlation with the development of rural area. The role of road in the access to education is clearly mentioned by Cesar Queiroz and Surhid Gautam (1992) as follows: "Road transport is an important sector of economic activity, especially in developing countries, where it plays an essential role in marketing agricultural products and providing access to health, education and agricultural inputs and extension service." 


\section{Access to Health Facility}

An indicator of the access to health facility in this present research deals with the difficulty or easiness of the people in going to and making use of the facility and infrastructure in order to realize the quality of the people.

The evaluation of this access involved the condition before and after the implementation of the policy of the road development in rural area in Mairasi. The results of the statistical data showed that the mean value of the access to health facility after the road was built was 2.44 which is higher than that before the road existed, namely 2.20. Statistically, the discrepancy is significantly meaningful since it has the $Z$ value of -7.226 with the p-value (Asymp. Sig 2-tailed) of 0,000 which is below the critical limit of the research, namely 0,05 . The decision is that Ho1 is not accepted and Halis accepted, meaning that there is a significant discrepancy of the access to the health facility before and after the road exists. Therefore, the policy of the road infrastructure development has effects on the changes of the access to the health facility in rural area in Mairasi.

The condition of changes may be shown by better accessibility to go and reach the facility and the infrastructure in order to realize the quality of the people. This actually happens since each kampong has had the health facility with its each status. This is presented in Table 2.

Table 2:- Number of Health Facility in Accordance with Kampong in Rural Areas in

\begin{tabular}{|l|c|c|c|c|}
\hline Kampong & $\begin{array}{l}\text { Community } \\
\text { Health Center }\end{array}$ & $\begin{array}{l}\text { Sub Community Health } \\
\text { Center }\end{array}$ & $\begin{array}{l}\text { Village } \\
\text { Maternity Place }\end{array}$ & $\begin{array}{l}\text { Family Planning } \\
\text { Clinic }\end{array}$ \\
\hline Jarati & - & - & 1 & - \\
\hline Werua & - & - & 1 & - \\
\hline Oray & - & - & 1 & - \\
\hline Sara & - & - & 1 & - \\
\hline Lobo & 1 & - & - & - \\
\hline
\end{tabular}

Source: Processed from Kaimana regency in number 2016, 2017.

The finding is confirmed with the participants' recognition. They recognized that after the road was built, they did not have any difficulty to get health services. The health staffs also stated that the road facilitated them to give travelling services to the people. However, there were also some participants who admitted that the convenience of the access to health services does not automatically encourage them to make use of the existing health services. They admitted that not all people in kampongs make use of the health services.

Health admittedly becomes one of the important elements in human life since it can support activities of economy and development. The importance of health in this case may be seen from the labors' participation. A healthily physical quality is one of the indicators of high-quality labors, which certainly will support the development of economy and development in a region. From the frame of mind, it can be seen that adequate health facility is a need. Health facility becomes a supporting infrastructure helping realize the quality of a healthy society. Such a healthy society certainly will contribute to healthy man power.

The access to health facility is related to the measure of the easiness or difficulty of a society goes to and uses the facility and the infrastructure to realize their life quality. Dardak (2005) stated that rural roads facilitate the people's reach to centers for social and cultural services such as health (Community Health Centers (puskesmas) and Integrated Service Post in Indonesia (posyandu). The people in rural area in Mairasi enjoyed the impacts of the policy of the road infrastructure development so that may improve their access to health facility. Moreover, health staffs were also easier to provide traveling services among the society. It can be concluded that the existence of road has a parallel relation to an easier access to health facility. The existence of road really helps the people's health be examined or get quicker health services. Moreover, the road also facilitates the health workers to give health services routinely and punctually. The usefulness of the road for the people in the rural area in Mairasi is in line with the Gannon, et al's (2001) finding that the situation of the people in rural areas before roads development or improvement is often marked by five hindrances. One of the hindrances, according to Gannon et al. is as follows: "Longer journeys are infrequent even though they may well be essential to livelihood strategies, such journeys include visits to hospitals and clinics. Therefore, Dunkin (1992) stated that when an access to health facility is better, the people will have "good health". 
The existence of road infrastructure in rural areas that supports the accessibility has an important correlation with the development in rural areas. Accessibility is certainly supported with transportation facility as Cesar Queiroz and Surhid Gautam (1991) put it: "Road transport is an important sector of economic activity, especially in developing countries, where it plays an essential role in marketing agricultural products and providing access to health, education and agricultural inputs and extension service."

The condition of change actually rebutted Warr's (2005) worries that limited road network will cause isolatedness that may hinder the people to go out from various problems in development such as low access to health facility.

\section{Access to the Market}

Market is a place where in general economic activities happen. It is a place for exchanging various resources (natural resources, economic resources). In this context, the government plays an important roles in reinforcing the market function to support the economic activities of the people. Market becomes a place in which the government may get the quality of good economic improvement. As a result, access to the market as a place where economic activities occur is something that is absolutely paid attention to. Infrastructure dealing with the market itself is also the people's access to the market that becomes an element that should be considered to create a good local economic quality.

An indicator of the access to the market in this present research deals with the measure of the people's easiness and difficulty to go to the place in which the economic resources in the form of buying-selling activities occur. The result of the statistical data showed that the mean value of the access to the market after the road existed was 2.35 , which is higher than that before the road was built, namely 2.04. Statistically, the discrepancy is significantly meaningful since it has the $Z$ value of -12.388 with the $p$ value (Asymp. Sig 2-tailed) of 0,000 which is below the critical limit of the research, 0.05. It means that the policy of the road infrastructure development has effects on the changes of the access to the market in rural area in Mairasi.

As a result, the policy of the road infrastructure development has a great effect on the change of the access to the market for the people who lives and does not live along the road in rural area in Mairasi. The road was not connected to the market, but the people still made use of the sea transport mode namely longboats or motorboats, where the port in Labo kampong becomes the transit place. However, the convenience of the access to the market gave an impact, namely improving the number of transportation tools including the vehicles for rural areas provided by the local government. The growth of the transport vehicles in rural area in Mairasi is presented in Table 3.

Table3:-Growth of the Transport Vehicles in Rural area in Mairasi

\begin{tabular}{|l|l|c|c|c|c|c|c|}
\hline & & \multicolumn{2}{|c|}{ Before the Road Exists } & \multicolumn{3}{c|}{ After the Road Exists } \\
\hline No. & Kampong & & & & & & \\
\hline & & Two- Wheel & Four-Wheel & Long Boat & Two-Wheel & Four-Wheel & Long Boat \\
\hline 1 & Lobo & 0 & 0 & 2 & 13 & 2 & 13 \\
\hline 2 & Jarati & 0 & 0 & 0 & 1 & - & 7 \\
\hline 3 & Werua & 0 & 0 & 1 & 1 & - & 4 \\
\hline 4 & Sara & 0 & 0 & 1 & - & - & 6 \\
\hline 5 & Oray & 0 & 0 & 0 & - & - & 5 \\
\hline
\end{tabular}

Source: Department of Transportation of Kaimana Regency, 2017

However, the people really felt a great change in their access to the market. The change condition was expressed by the society, prominent figures, and also the government. There thought that the road facilitated the people to bring their agricultural products to the market and in return they could more easily bring household appliances including building materials to their kampongs. Because of the existence of the road, the shift of their transport pattern, from the traditional fashion using human beings that takes a lot of time to walk into the more modern way, occurred. In effect, the cost for transport is lower but the volume is unlimited. The result of the statistical data is confirmed where a change of travelling time and expense spent before and after the existence of the road in rural area in Mairasi has occurred. For more information, see Table 2.

Table 4:-Travelling Time and Expense Before and After the Existence of the Road

\begin{tabular}{|l|l|l|l|l|l|}
\hline Road & Destination & Time & $\begin{array}{l}\text { Before the Road } \\
\text { Exists }\end{array}$ & $\begin{array}{l}\text { After the Road } \\
\text { Exists }\end{array}$ & $\begin{array}{l}\text { Change } \\
(\Delta)\end{array}$ \\
\hline
\end{tabular}




\begin{tabular}{|l|l|l|l|l|l|}
\hline & $\begin{array}{l}\text { Capital City of } \\
\text { Kaimana Regency }\end{array}$ & Expense & & & \\
\cline { 2 - 6 } & a.Lobo Kampong & Minute & 120 & 120 & \\
Lobo- & & Rp./Person & Rp.800,000 & Rp.800,000 & Rp.0.00 \\
\cline { 2 - 6 } \begin{tabular}{l} 
Waranggatnao- \\
\cline { 2 - 6 }
\end{tabular} & b.Jarati Kampong & Minute & 4440 & 360 & 4,08 \\
& & Rp./Person & Rp.4,800,000 & Rp. 1000,000 & Rp.3,800,000 \\
\cline { 2 - 6 } & c.Werua Kampong & Minute & 5880 & 660 & 5220 \\
& & Rp./Person & Rp.6,800,000 & Rp.2,200,000 & Rp.4,600,000 \\
\cline { 2 - 6 } & d.Sara Kampong & Minute & 6060 & 6060 & 0.00 \\
& & Rp./Person & Rp.7,000,000 & Rp.7000,000 & 0.00 \\
\cline { 2 - 6 } & e.Oray Kampong & Minute & 4560 & 360 & 4200 \\
& Rp./Person & Rp.4,880,000 & Rp. 1000,000 & Rp.3,880,000 \\
\hline
\end{tabular}

Source: Results from the processed research primary data, 2017

The data showed that a significant change has happened to the people in the rural areas in Mairase after the road was built. The change deals with three indicators of accessibility namely time, cost and mobility where the travelling time is shorter, the transportation cost is lower and the mobility is higher. The changes are various, but a significant change has happened to Jarati kampong since this kampong is directly impacted by the road. In the past, the travelling time from this kampong to the market was 3456 minutes but now it becomes 360 minutes, so the travelling time reduction is $960 \%$; the travel expense to the market has also changed from Rp.4,800,000.00 into Rp. $1,000,000.00$ or the decrease is $480 \%$.

Determining the travel expense to the market to bring their agricultural products consists of two components namely the transportation expense for men and goods. For men, the expense is calculated from the need for fuels to go to and fro, while for the expense for goods, it is calculated based on the percentage which is divided with the service given by men to bring or carry the goods. It is in line with what had been expressed by a farmer in Jarati kampong: "Before the road was built, when we wanted to go to the market to sell nutmeg, we should share the money with the man bringing the goods. We got less share than the man who brought the goods, but we can't do nothing, we need money." (JA, July, 2017). The third indicator is mobility or trip generation, which has also improved. Indeed, mobility or travel level is not measured on the basis of the calculation of the people who go to and fro the market, but on the existence of transport unit. Before the road was built, the transport units were 34, but after the road was built, this number increases, namely 105 units or 309\%, indicating that the people's mobility or the travel level in the rural area in Mairasi was high.

The increase in the accessibility gave impacts on the people in the area of Mairasi where statistically, the existence of the road significantly influenced the socio-economic change. On the basis of the data above, it can be stated that the people in Mairasi thought that the presence of the road gave effects on the improvement of incomes from the results of seling commodities. The easiness of the access to the market gave effects on the improvement of selling the products, then the improvement of the selling the products caused the improvement of the incomes, then the increasing incomes make the people have more rational choices in improving their prosperity, including sending their children to continue their study in the cities, even if the fell sick, they may chose to see the doctor in the cities. Moreover, they started building their permanent houses to replace their houses on stilts. They afforded to pay subscription for electricity or water. One of the prominent figures, Bamuskam Lobo expressed their experiences of how incomes are important to improve their prosperity, especially the service for fresh water.

"Once, a staff from the water company cut the water network because one did not pay the subscription as mutually agreed. The owner of the house was an elderly who could not work anymore to get money to pay the subscription, but the staff stated that the elderly (paitua) had children and they may pay the subscription, why didn't they help the elderly pay it" (JW, July, 2016).

From the story, it can be stated that incomes influence one's prosperity level, especially one's access to public services.

The policy of the road infrastructure development makes the people in kampongs improve their economic level, namely increasing the farmers' incomes because the transport volume of agricultural and plantation and also fishery products is higher since it is trucks which are used. The existence of the road infrastructure in the rural areas 
supporting this accessibility had an important correlation with the development in rural areas. It is in line with Cesar Queiroz dan Surhid Gautam's (1992) statement that "Road transport is an important sector of economic activity, especially in developing countries, where it plays an essential role in marketing agricultural products and providing access to health, education and agricultural inputs and extension service".

The policy of the road development in rural areas is the realization of the equity feeling which was expressed by the regent of Kaimana in the meeting forum of regents from Papua land, held in Bintuni in 2013 that "the policy is based on the consideration "One rupiah of the local budget in Kaimana regency is also possessed by the people in kampongs or in isolated peripheral areas."

\section{Access to Banking}

The indicator of the access to banking in this present research is related to the high or low activities in the people's savings and loan in the bank. The people living in the rural area in Mairasi admitted that the road infrastructure development encouraged them to access to bank. It can been from the statistical data showing that the mean value of the access to banking after the road was build was 2.54, which is higher than that of 2.03 before the road existed. Statistically, the discrepancy is significantly meaningful since it has the $Z$ value of -11.827 with the $p$-value (Asymp. Sig 2-tailed) of 0.000 below the research critical limit of 0,05 .

The results of the analysis showed that the change of access to banking not only happen to the kampongs where the road passed through, but also to the ones did not passed through by the road. But, the change of the condition turned out mostly happening to the kampongs where the road did not pass through. The people who do not dwell along the road in the rural area in Mairasi mostly accessed to banking than those along the road. The results of the statistical data are reinforced by the customers of PT Bank Pembangunan Daerah Papua, Kaimana Branch. See Table 5.

Table 5:-Customer of PT Bank Pembangunan Daerah Papua, Branch of Kaimana

\begin{tabular}{|c|c|c|c|c|c|c|}
\hline No & & $\begin{array}{c}\text { Number of } \\
\text { Customer }\end{array}$ & \multicolumn{4}{|c|}{ Year (Rp.) } \\
\hline & Kampong & & 2013 & 2014 & 2015 & 2016 \\
\hline 1 & Lobo & 9 & $61,275,842$ & $60,899,943$ & $16,154,692$ & $8,418,735$ \\
\hline 2 & Jarati & 6 & $1,151,703$ & $1,819,871$ & $568,847,906$ & $1,075,354,847$ \\
\hline 3 & Werua & 11 & $18,671,696$ & $47,404,515$ & $667,815,773$ & $388,907,827$ \\
\hline 4 & Oray & 5 & 0 & 453,208 & $661,028,511$ & $441,491,370$ \\
\hline 5 & Sara & 7 & $51,226,196$ & $51,226,196$ & $598,708,567$ & $1,127,263,71$ \\
\hline
\end{tabular}

Source:: PT Bank Pembangunan Daerah Papua, Branch of Kaimana.

Moreover, the data are confirmed through the recognition of the people, the prominent figures and the government. They in general recognize that the policy of the road infrastructure development had encourage them to access to banking. They used the sales of their agricultural and plantation products not only to buy the daily needs but also to save in the bank. In essence, the presence of the road had changed their saving habits from saving their money at home into saving in the bank. It is expressed by one of the people in Jarati, "I used to save money in a bamboo, but when I went out of town to buy household needs, the money did not prevail so I had to go to the bank to exchange it. Because of that, I save money in the bank so that it is easier for me to buy anything. I just go to the bank to take it." ( PA, July 2017). The people in the rural area in Mairasi felt the benefits from the saving. They could save money in the bank to prepare the expenses for their children's education or for their household needs.

However, there are some participants who admitted that the policy of the road infrastructure development had not significantly encouraged them to access to banking, because their incomes had not increased yet. They were still trying to fulfill their daily needs. Moreover, there were also people who made use of their incomes to pay the expenses for their children's education or people who spent most their incomes for their daily needs, and the like so that they could not save anymore. Life style changes also influence their saving habits.

Access to banking is the people's effort to save their incomes. Keynes (1946) stated that principally incomes are the function of consumption, savings and investment. Incomes also refer to one's social status as Dutton and Levine (1989) put it that socio-economic status is "a composite measure that typically incorporates economic status, measured by income; social status, measured by education; and work status, measured by occupation." 
Some people did not access to banking because their incomes were not enough to pay for their daily lives. Lipton (1977) called this condition as a consequence of the urban bias for less lucky persons in rural areas in terms of access to financial services. They did not save their incomes because they had to fulfill their children's educational needs. Their expenses were getting high. They were tempted to buy stuffs in the city so that they spent their incomes to buy anything they wanted. It is certainly related to the lifestyle of the people living in the rural area in Mairasi. This change of behavior_according to Lipton (1977) becomes one of the urban biases. Moreover, the change of behavior according to Ajayi (1996) is social economic effect, namely the ultimate change in the living conditions of beneficiaries resulting wholly or partially from a project or program." Meanwhile, Dunkin (1992) explained the socio-economic effects as follows: "it is a patterned social behavior and finances of individuals in the society, which is the outcome of project effects. Therefore, all changes become an important facility to estimate the level and the quality of human development.

\section{Evaluation of the Performance of the Policy of the Road Infrastructure}

Road is the realization of social equity. Road is able to change the pattern of the movement of people and good from the traditional pattern, using human beings and animals as the transport tool into the modern pattern using motor vehicles. The pattern of movement caused the change in dimensions of time, expense and travelling (trip). A better access to the market resulted in higher products which in turn cause higher sales and also which makes higher incomes. This in turn improves their standard of living which can be seen from their renovating their houses into permanent ones with good sanitation as a form of investment and saving. The people also had rational choices for further education and better health services with high-quality medical staffs and doctors.

Therefore, as part of the evaluation of the policy, the evaluation of the performance of the road infrastructure development is presented in Table 6.

Table 6:-Evaluation of the Performance of the Policy of the Road Infrastructure Development

\begin{tabular}{|c|c|c|}
\hline Criteria & Parameter & Attainment Indictor \\
\hline Effectiveness & $\begin{array}{l}\text { This criterion is closely related to the technical } \\
\text { rationality, which is always measured from the } \\
\text { values of products or services or its monetary value. } \\
\text { A policy that reaches the highest effectiveness with } \\
\text { the least expense }\end{array}$ & $\begin{array}{l}\text { The existence of the road significantly influences } \\
\text { the access to education, health, market and to } \\
\text { banking. } \\
\text { Weatherproof Solid Aggregate Road (JAPAT) } \\
\text { model is the choice of construction with the least } \\
\text { cost from the road construction type, but } \\
\text { technically it is able to give services effective for } \\
\text { the users especially in reducing the logistic cost } \\
\text { and travelling time. }\end{array}$ \\
\hline \multicolumn{3}{|r|}{ 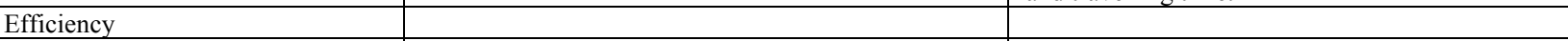 } \\
\hline Adequacy & $\begin{array}{l}\text { This criterion is related to how far a level of } \\
\text { effectiveness may satisfy the needs, values, or } \\
\text { opportunities to elicit problems. Adequacy criterion } \\
\text { gives an emphasis on the strong relationship } \\
\text { between alternative policies and the expected results }\end{array}$ & $\begin{array}{l}\text { The existence of an effective road narrows down } \\
\text { socio-economic gaps. Road becomes an } \\
\text { ideological bridge. }\end{array}$ \\
\hline Equity & $\begin{array}{l}\text { This criterion is related to the legal and social } \\
\text { rationality and refers to the distribution of results } \\
\text { and efforts among different groups in the society. An } \\
\text { equity-oriented policy is the policy where causes or } \\
\text { efforts are justly distributed }\end{array}$ & $\begin{array}{l}\text { The people feel that road is the social or economic } \\
\text { vein. The existence of a road promotes the } \\
\text { growth of assets through kiosks, livable homes, } \\
\text { longboats, motorcycles, and saving }\end{array}$ \\
\hline Responsiveness & $\begin{array}{l}\text { Responsiveness deals with how far a policy may } \\
\text { satisfy needs, preferences, or values of certain } \\
\text { groups of people. }\end{array}$ & $\begin{array}{l}\text { The existence of a road is the realization of } \\
\text { attention. Indonesia has got its independence for } \\
73 \text {, but the existence of the road ensures that } \\
\text { independence from isolatedness is reached. }\end{array}$ \\
\hline Appropriateness & $\begin{array}{l}\text { Accuracy refers to the value or the price of a goal of } \\
\text { a program and the strong assumptions serving as } \\
\text { the basis of the goal. Meanwhile all other goals do } \\
\text { not question the goal, namely do not question the } \\
\text { value of efficiency and sameness, but it is the } \\
\text { criterion of appropriateness that even questions } \\
\text { whether the goal is appropriate for a society. }\end{array}$ & $\begin{array}{l}\text { The choice of developing the Lobo-Jarati-Matua } \\
\text { road from the economic calculation must not be } \\
\text { feasible but the road development done is the } \\
\text { realization of the state attendance or state } \\
\text { obligation }\end{array}$ \\
\hline
\end{tabular}

Therefore, the policy of the road infrastructure development had significant impacts on the socio-economic changes to the people in the rural areas in Mairasi and also reduced the existing gaps. The change also rebuts the positive 
cycle proposed by Raknar Nurkse on the vicious cycle of poverty where the policy of the road infrastructure development in the rural area in Mairasi gave impacts on the increasing agricultural and plantation products as the result of the shorter travelling time, the cheaper travelling expenses, and also higher volume to the market. This condition may produce multiple effects: since the farmers' positions and incomes increase, they may save more, their more savings make the investment higher and such a higher investment will reinforce the capital. Then, no gap between the incomes in rural areas and urban ones occur, and this in turn improves the people's prosperity. It is the fruit of the social equity which in other words is called the proportional cycle of prosperity. The flowchart of the impacts of the road infrastructure development on the socio-economic change among the people living in the urban areas in Mairasi is presented in Table 6.
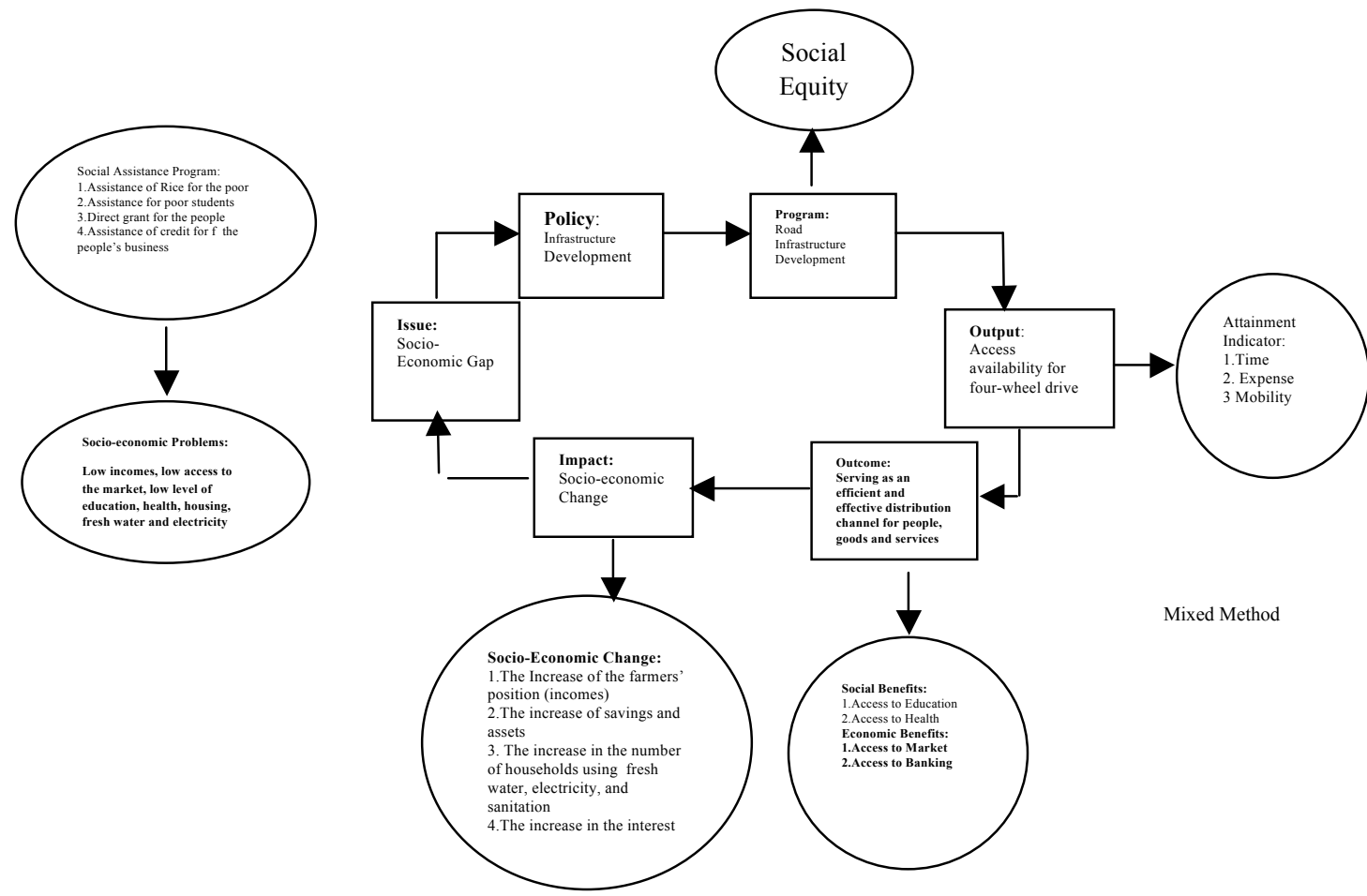

Picture 6:-Impacts of the Road Infrastructure Development on the Socio-economic Change among the People Living in the Urban Areas in Mairasi

\section{Conclusion:-}

Good accessibility will boost the growth of transportation which is measured on the basis of three main indicators namely time, expense and mobility (trip generation). Road as the realization of accessibility is able to change the pattern of the movement of people, goods and services from the traditional pattern making use of human beings and animals as the transportation tool into the modern pattern using motor vehicles. The movement pattern makes sure the change in the dimensions of time, expense and trip. The improvement of accessibility to the social aspect gives significant impacts on the access to education with the mean value of 2.40 after the road exists which is higher than before the road is built, namely 2.29 . The discrepancy statistically gives significant meaning since it has the $\mathrm{Z}$ value of -5.122 with the p-value (Asymp. Sig 2-tailed) of 0.000 which is below the research critical limit of 0.05 . The same impact happens to the access to health with the mean value of 2.44 after the road is built where this value is higher than that before the road exists, namely 2.20. Statistically, the discrepancy is significantly meaningfull since the value of the Z-value is -7.22 with the p-value (Asymp. Sig 2-tailed) of 0,000 which below of the research critical limit, namely 0,05 . Moreover, the improvement of the accessibility to the economic aspect gives impacts on the access to the market with the mean value of 2.35 after the road is built. This mean value is higher than that before the road exists, namely 2.04 . The discrepancy statistically significant since it has the Z-value of -12.388 with the pvalue (Asymp. Sig 2-tailed) of 0,000 where this value is below the research critical limit of 0.05 . The same impacts also happens to the access to banking with the mean value of 2.54 after the road exists. This value is higher than 
2.30 before the road is built. Statistically, the discrepancy is significantly meaningful because of the $\mathrm{Z}$ value of 11.827 with the p-value of (Asymp. Sig 2-tailed) 0.000 which is below the research critical limit of 0,05 .

The results of the statistical calculation showed that the policy of the road infrastructure development as the realization of the improvement of accessibility has given significant impacts on the socio-economic change among the people living in the rural area in Mairasi namely the access to education, health, market and to banking. The improvement also ensures that some reductions of gap have happen to the people in the rural area in Mairasi indicated by the increase of the children at the school age who continue their study in the city. moreover, the people more easily access to the health services either in the kampong or in the city if their diseases need a higher level of treatment. The convenience of access to the market makes the people able to improve their buying-selling activities, even access to banking also increases. The socio-economic change is related to the human building namely education, health and purchasing power parity. Road is the realization of social equity since it is able to change the movement pattern of human beings, goods and services from a traditional pattern using human beings and animals as the transportation to into a modern pattern using motor vehicles.

Therefore, the road development in the rural area in Mairasi is the distribution of equity in fulfilling the equity and equality principles.

\section{Suggestions}

This present research certain has some limitations either technically or substantially. Technically, this present research has not been able to generalize the condition of the socio-economic changes in Kaimana regency, especially and in general in Papua and West Papua provinces due to its scope of the research locus. Meanwhile, the substantial limitation is that this research has not been able to explore all impacts of the policy of the road infrastructure development on the socio-economic changes as one of the realizations of the social equity in Kaimana regency, and Papua and West Papua provinces in general. Therefore, it is suggested that future researches should widen the locus or the socio-economic variables.

To the policy makers or the government, it is suggested that they design the policy of the road development in rural areas in the context of the acceleration of the area which based on the approach of the connectivity between front and isolated peripheral areas. Certainly, it needs a great financial resources. Therefor, it is necessary to consider the priority in handling the construction of the road by adopting what is called Weatherproof Solid Aggregate Road (JAPAT) by constructing the road without asphalt. Therefore, the performance of a road may provide a minimum standard of service namely the road may be passed by four-wheel drive vehicles in low speed but the people may directly enjoy the benefits of the road although the road has not fulfilled the security and safety criteria.

The model of the road management approach in the rural area, viewed from a public policy, will produce a proper policy in terms of the service effectiveness, construction cost efficiency, responsiveness to isolatedness, and equality to reduce the gap, and also adequacy to solve any socio-economic problems and to fulfill the equity aspect namely maximizing the people's prosperity living in the rural area in Mairasi.

\section{References:-}

1. Bandur, Agustinus. 2013. Penelitian Kuantitatif: Desain dan Analisis Data dengan SPSS. Yogyakarta: Depublish.

2. Creswell, Jhon W., 2005. Research Design: Qualitative, Quantitative, and Mixed Methods APPROACheS. USA: SAGE PUBlicAtions, InC.

3. Dardak, Hermanto. 2005. "Pengembangan Jaringan Jalan Wilayah Sumatera Berbasis Penataan Ruang." Makalah, disampaikan pada Konferensi Regional Teknik Jalan Ke-8 Wilayah Barat di Batam pada tanggal 2829 JuliDunkin (1992)

4. Dunn, William N. 1981. Public Policy Analysis: An Introduction, Third Edition. New Jersey: Pearson Prentice Hall.

5. Dutton, D.B., and Levis, S. (1989), Overview, Methodological Critique, and Reformulation, in J.P. Bunker, D.S. Gomby, and B.H. Kehrer (Eds.), Pathways to Health. Melno Park, CA: The Henry J. Kaiser Family Foundation, pp. 29-69.

6. Dye, Thomas R. 1992. Understanding Public Policy, $7^{\text {th }}$ Edition. New Jersey: Prentice Hall, Englewoods Cliff.

7. Gortner, Harold F. 1981. Administration in the Public Sector. Canada: John Wiley \& Sons, Inc.

8. Haas, R., Guy Felio, Zoubir Lounis, Lynne Cowe Falls, 2009, "Measurable Performance Indicators for Roads: Canadian and International Practice", Paper Prepared for Presentation at the "Best Practices in Urban 
Transportation Planning: Measuring Change" Session at the 2009 Annual Conference of the Transportation Association of Canada Vancouver, British Columbia.

9. Iek, Mesak. 2013. "Analisis Dampak Pembangunan Jalan terhadap Pertumbuhan Usaha Ekonomi Rakyat di Pedalaman May Brat Provinsi Papua Barat (Studi Kasus di Distrik Ayamaru, Aitinyo, dan Aifat)." Jurnal Ekonomi Kuantitatif Terapan, Vol. 6, No. 1, hal. 30-40.

10. Lipton, Michael. 1977, Why Poor People Stay Poor: A Study of Urban Bias in World Development. London: Temple Smith.

11. Neuman, W. Lawrence. 2006. Social Research Methods. USA: Pearson Education, Inc.

12. Peraturan Presiden Republik Indonesia Nomor 65 Tahun 2011 tentang Percepatan Pembangunan Provinsi Papua dan Provinsi Papua Barat.

13. Peraturan Presiden Republik Indonesia Nomor 84 Tahun 2012 tentang Pengadaan Barang/Jasa Pemerintah dalam rangka Percepatan Pembangunan Provinsi Papua dan Provinsi Papua Barat.

14. Queiroz, Cesar and Surhid Gautam. (1992). Road Infrastructure and Economic Development: Some Diagnostic Indicator: Some Diagnostic Indicators. Washington D.C: World Bank.

15. Rao, Lakshmana dan K. Jayasree. 2003. "Rural Infrastructure Planning with Emphasis on Road Network Connectivity by Coplanar Concurrent Theory." Map India Conference.

16. Sarkar, Ashoke K. dan M. A. M. Mashiri. 1998. Quantification of Accessibility Levels of Rural Areas: A Case Study in the Northern Province South Africa. Pretoria: Transportek, Council of Scientific and Industrial Research.

17. Todaro, Michael P. dan Stephen C. Smith. 2003. Economic Development, Eight Edition. Boston: AddisonWesley.

18. Undang-Undang Nomor 38 Tahun 2004 tentang Jalan.

19. Warr, Peter. 2005. "Road Development and Poverty Reduction: The Case of Lao PDR." ADB Institute Discussion Paper No. 25, February.

20. Maria Goretti Oktaviana, Harnen Sulistio, Achmad Wicaksono, Strategi Pengembangan Transportasi Antar Wilayah Di Provinsi Papua Barat, Jurusan Teknik Sipil, Fakultas Teknik, Universitas Brawijaya Malang, 2011

21. La Ode Muhamad Maghriby dan AJ Suharjo, Aksesibilitas dan pengaruhnya terhadap pembangunan di pedesaan. Jurnal Transportasi Vo.4 No.2 2004

22. Sen, Amartya, K. 1981."Poverty and Femine: An Essay on Entitte and Deprivation". 